\title{
Organoclay-Polymer Nanocomposites
}

\begin{abstract}
The properties of polymer nanocomposites exceed the properties of common composite materials due to the nanoscale size and morphology of the fillers used.Particulate fillersare commonly used in polymers forimproved mechanical and thermal properties, as well as modified electrical properties and cost reduction. Organically modified layered clays,such asmontmorillonite, are among the most widely used fillers for the improvement of polymer matrices. Presented in this review are some of the most studied clay nanocomposites including clay-polyolefin, clay-polyester and clay-thermoplastic polyurethanenanocomposites. Additionally, the properties of clay-biopolymers nanocomposites will also be discussed.
\end{abstract}

Keywords: organically modified clays, montmorillonite, polymers, nanocomposites, properties

\section{INTRODUCTION}

Polymer nanocompositeshave been intensively studiedover the past decade [1]. They are defined as an interacting two phase mixture, i.e. a polymer matrix and a solid phase. The properties of polymer nanocompositesexceed the properties of common composite materials due to the nanoscale size and morphology of thefillers used.Proper dispersion of the filler within the polymer matrixisachieved by first breaking down the layered materials (i.e.graphite, clays, etc.) into their nanoscale building blocks and mixing them into the polymer matrix.This approach is widely used for the preparation of clay/polymer nanocomposites [2]. Nanofillers have the following advantages over traditional fillers: low-percolation threshold ( 0.1-2 vol.\%), large number of particles per particle volume $\left(106-108\right.$ particles $\left./ \mu m^{3}\right)$, high aspect ratio $\left(103-104 \mathrm{~m}^{2} / \mathrm{mL}\right)$, and short distances between particles (10-50 $\mathrm{nm}$ at $\sim 1-8$ vol.\%) [3]. The effect of nanofillers on polymer composites depends on the nanofiller geometry (aspect ratio, size and shape of particles), the particle-matrix interactions (compatibility (wettability)), and volume fraction $[4,5]$. Some of the more common reasons of particulate filler usein polymers matrices include: increased stiffness, increased strength and dimensional stability, increased toughness and heat distortion temperature, increased damping, decreased permeability, modified electrical properties and cost reduction $[6,7]$.

Author's address: ${ }^{1}$ Department of Chemical Engineering, McMaster University, Hamilton, ON, Canada, ${ }^{2}$ College of Vocational Studies Belgrade Polytechnic, Belgrade, Serbia, ${ }^{3}$ Technical Faculty in Bor, University in Belgrade, Bor, Serbia, 4Faculty of Technology and Metallurgy, University of Belgrade, Belgrade, Serbia

Received for Publication: 26. 02. 2014.

Accepted for Publication: 16. 04. 2014.
The organically modified layered clays, i.e. smectite clays, are one of the more widely used particulate fillers for improving mechanical and barrier properties, as well as thermal stability of different polymer matrices. Among smectites, the most utilized clay is montmorillonite (MMT) due to its rich intercalation chemistry, low price and natural availability. This rich intercalation chemistry allows chemical modification of MMT to make it compatible with organic polymers.
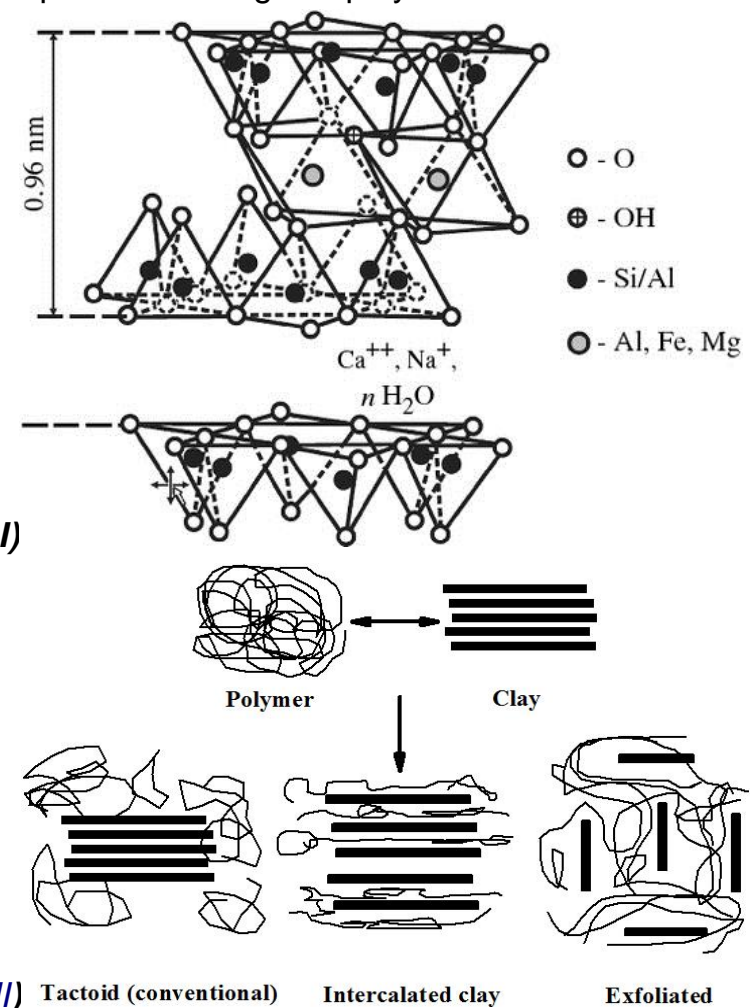

Figure 1 - Structure of montmorillonite clay(I) [10] and schematic of possible NC structures when

mixing organoclays with polymer matrix.

Presented in Figure 1-I is MMT which is a 2:1 layered smectite clay mineral with a plate-like structure. MMT is hydrophilic in nature due to the 
presence of cations such as $\mathrm{Na}^{+}$. To make MMT hydrophobic and compatible with hydrophobic polymer matrices, modification of MMT must be performed. Common proceduresinvolves surface modification of MMT through cation exchange reactions with quaternary ammonium organic salts. Organic modification of MMT ensures a better dispersion of the fillerwithin the matrix. However, MMT cannot be easily dispersed due to the restacking in agglomerated tactoids despite its high aspect ratio [8]. True nanocomposites are obtained only if the clay nanolayers are completely exfoliated and dispersed within the polymer matrix. Three possible, intercalated NC structures,are illustrated in Figure 1-II.Intercalation and exfoliation are two desirable NC structures dependent on the type of organoclay and processing conditions [9].

The aim of this review is to summarize and present recent achievements in the field of organoclay-polymer NCs.

\section{ORGANOCLAY-POLYMER NANOCOMPOSITES}

Polymer NCs can be prepared through solution mixing of polymer and filler, in situ polymerization and melt processing.In situ and melt blending preparation of polypropylene (PP)/clay nanocomposites (PPCNCs) was reported by Baniasadi et al [11]. In thecase of in situ preparation of PPCNCs, bentonite clay (sodium montmorillonite, $\mathrm{Na}^{+}-\mathrm{MMT}$ ) was incorporated into PP through Ziegler-Natta (ZN) polymerization of propylene. The bi-supported ZN catalyst of $\mathrm{TiCl}_{4} / \mathrm{Mg}(\mathrm{OEt})_{2} /$ clay was prepared and used for propylene polymerization in a slurry polymerization process. A second batch ofmelt blended PPCNCswere made by mixing pure PP and PPCNCusing organically modified clay(OMC) with hexadecyl therimethylammonium bromide. It is worth noting that PP was not modified with maleic anhydride (often used as a compatibilizer for PP and PE) to enhance the compatibility of PP with clay. In situ polymerization with a ZN bi-supported catalyst was used to enhance compatibility during preparation ofthe PP/OMC NCs. X-ray diffraction (XRD) revealed complete exfoliation of OMC in situ-PPCNCs (Fig. 2a) while for melt-blended PPCNCs intercalation of OMC was observed (Fig. $2 b)$. Further analysis using transmission electron microscopy (TEM) proved uniform distribution and an exfoliated structure of in situ-PPCNCs. Both exfoliated structure and strong interaction between filler and matrix (i.e. MMT platelets and PP) produced the NCs with improved physical, mechanical and thermal properties. Yield strength, tensilestrength and the storage modulus were significantly increased for clay containing in situ-PPCNCs compared with pure PPs. In all cases, melt-blended PPCNC with $3 \%$ OMC had values below those of in situ-PPCNC with $1 \%$ clay. Also, improved thermal properties of in situ-PPCNCs, compared with pure PP and melt-blended PPCNC with $3 \%$ clay, were observed using thermogravimetric analysis (TGA) while increased crystallization temperature (Fig. 3) was observed using differential scanning analysis (DSC).

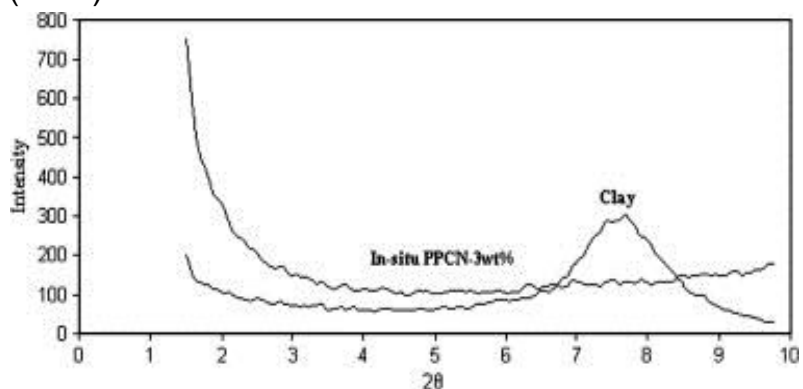

a)

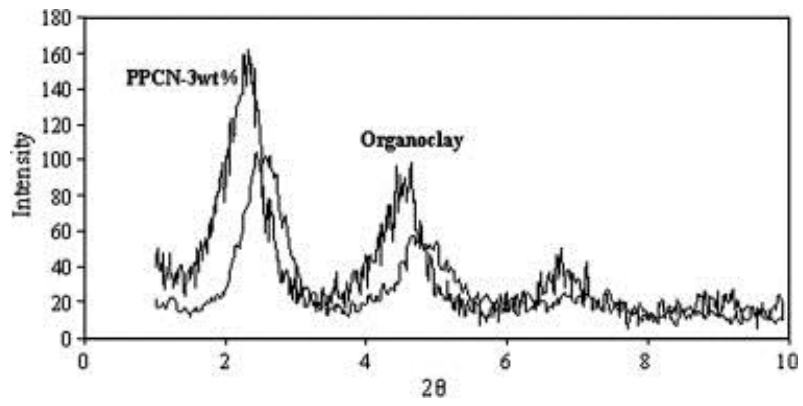

b)

Figure 2-X-ray diffractograms of in situ-PPCNC with $3 \%$ of clay(a) and melt-blended PPCNC with $3 \%$ of OMC [11].

Olewnik et al [12] used a different approach over Baniasadi forthermal stability of PP/clay and $\mathrm{PE} /$ clays. They investigated the effects of MMT surface modification with the surfactant and varying the amount of organic modifier in the MMT. From the obtained results it one can conclude that modified MMT improved thermal properties. However, with content higher than $5 \mathrm{wt} \%$ modified MMT, two opposing effects of modified MMT on the polymer matrix were observed. The first is barrier effect improving thermal stability and the second is a catalytic effect leading to decreased thermal stability.

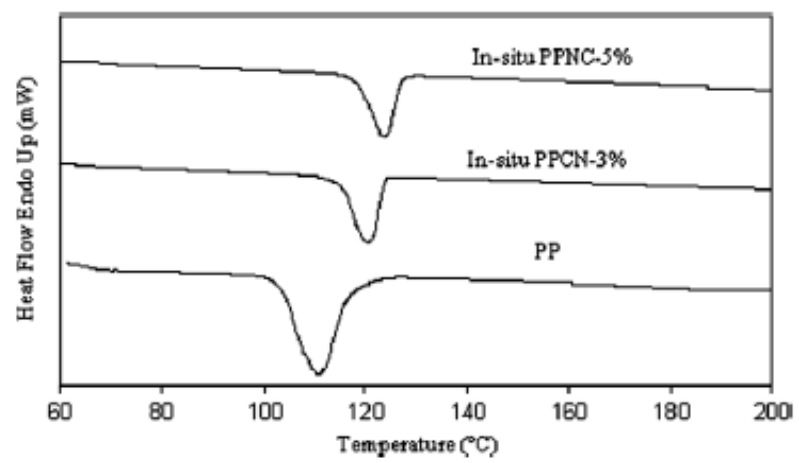

Figure 3-DSC cooling thermograms of in situPPCNCs and pure PP [11]. 
Along with improvements in mechanical and thermal properties, the influence of clay on rheological behavior of the polymer matrixis important and has major effect on processability of claypolymer composites. Dynamic melt rheometry (RMS) is a powerful method for the studying the effects of inorganic layered fillerson polymer chain dynamics.Melt rheology measurements of NCs prepared from maleic anhydride modified PP and Cloisite $15 \mathrm{~A}$ as the organically modified montmorillonite (OMMT) nanoclays were reported by Ataeefard and Moradian [13]. An increase in storage and loss moduli of the NCs with increased clay content and frequency, was observed when compared with the pristine counterpart. This means that relaxation times of the NCs increased with filler content due to strong filler-matrix interaction. Also, complex viscosity was higher with higher loadings of nanoclays in PP and it decreased with frequency due to the strong shear thinning behavior of the PPCNCs and pure PP. The viscosity of the PPCNCs melts was higher compared with melt viscosity of pure PP which is attributed to the strong interaction of the OMC and PPmatrix [14].

Similar to the in situ preparation ofPPCNCs using a ZN bi-supported catalyst, Nikolaidis et al [15], replaced PP with poly(methyl methacrylate), PMMA, to make PMMA/OMMT claysNC. Additionally, different types of OMMT clays classified under different commercial name Cloisiteetc. (Table 1) and different types of modifiers were used to evaluate the OMMT influence on thePMMA polymerization rate and properties, respectively. NCs with different loadings of OMMTs (Cloisite $\mathrm{Na}^{+}$, Cloisite 30B, Cloisite 25A, and Cloisite 15A) were prepared through bulk polymerization of methyl methacrylate (MMA). OMMTs were dispersed in the MMA prior to polymerization. Morphology analysis revealed complete exfoliation at the lower OMMT loadings (up to $1 \mathrm{wt} \%$ ) while partially exfoliated and intercalated structures were observed in NCs with OMMT loadings higher than $1 \mathrm{wt} \%$. Interestingly, a kinetics study of polymerization rates in the presence of different OMMTs revealed that the type of OMMT had an influence on the onset of the gel-effect,allowing it to occur earlier, while the type of modifier for OMMT did not affect polymerization kinetics. Moreover, unmodified MMT (Cloisite $\mathrm{Na}^{+}$) decreases the conversion vs. time of the MMA and thus, acts as a retarder whilethe opposite effect was observed in OMMTs at loadings lower than $1 \mathrm{wt} \%$. In addition, different properties of the PMMA/OMMT NCs were reported when different OMMTs were used. The highest improvements formechanical properties (tensile strength and tensile modulus) were obtained in the case of Cloisite $15 \mathrm{~A}$ and $25 \mathrm{~A}$, respectively, while the maximum improved thermal stability was in NCs with the Cloisite 25A at $1 \mathrm{wt} \%$ loading.

Besides mechanical and thermal property improvements, OMC are used for flame retardation due to their thermally stable nanosized particles.A good dispersion of filler in polymer matrix will result in a nanocomposite with improved properties evenat low loadings. Wang et al [16] investigated the fire retardancy of PMMA composites prepared with differentOMCs includingMMT, layered double hydroxide (LDH) and kaolinite, through melt blending. Prepared samples were subjected to cone calorimetry testingto determine flammability characteristics of PMMA/MMT, PMMA/LDH and $\mathrm{PMMA} /$ kaolinite NCs, respectively.

Table 1 -Different Cloisites and modifiers used, together with their cation exchange capacity (CEC) and the $d_{001}$ spacing measured by $W A X D^{a}$. [15]

\begin{tabular}{|c|c|c|c|}
\hline Sample & Organic modifier & $\begin{array}{c}\text { CEC } \\
\text { (meq } / 100 \mathrm{~g} \\
\text { clay) }\end{array}$ & $\begin{array}{c}d 001 \\
(\AA)\end{array}$ \\
\hline $\begin{array}{l}\text { Cloisite } \\
\mathrm{Na}+\end{array}$ & none & 92 & 11.8 \\
\hline $\begin{array}{l}\text { Cloisite } \\
\text { 30B }\end{array}$ & $\begin{array}{c}\stackrel{\mathrm{CH}_{2} \mathrm{CH}_{2} \mathrm{OH}}{\mathrm{l}} \\
\mathrm{H}_{3} \mathrm{C}-\mathrm{N}^{ \pm}-\mathrm{R}^{\prime} \quad \mathrm{Cl} \\
\stackrel{\mathrm{CH}_{2} \mathrm{CH}_{2} \mathrm{OH}}{ }\end{array}$ & 90 & 17.9 \\
\hline $\begin{array}{l}\text { Cloisite } \\
25 \mathrm{~A}\end{array}$ & 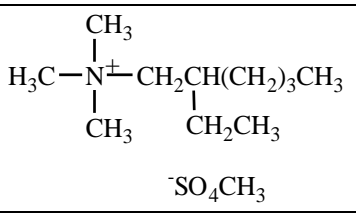 & 95 & 19.1 \\
\hline $\begin{array}{l}\text { Cloisite } \\
15 A\end{array}$ & $\mathrm{H}_{3} \mathrm{C}-{\underset{\mathrm{I}}{\mathrm{N}}}_{\mathrm{N}}^{\mathrm{CH}_{3}} \mathrm{R} \mathrm{Cl}^{-}$ & 125 & 29.4 \\
\hline
\end{tabular}

$\mathrm{R}$ and $\mathrm{R}^{\prime}$ are hydrogenated tallow and tallow ( 65\% C18, 30\% C16, 5\% C14, respectively).

Cone calorimetry is a very useful method in material flammability analysisbased on the oxygen consumption principle. PMMA/MMT and PMMA/LDH nanocomposites were found to have higher thermal stability as compared with PMMA/kaolinite composite and neat PMMA. Strong reduction of the peak heat release rate (PHRR)was observed in PMMA/MMT and PMMA/LDHNCs while PHRR reduction for the $P M M A / k a o l i n i t e$ composite was not significant. However, the improvement in ignition time (obtained longer time of ignition) was achieved only in the PMMA/MMTNC. Based on morphological and thermal analysis of prepared composites it was found that PMMA/MMT, $\mathrm{PMMA} / \mathrm{LDH}$ and PMMA/kaolinite composites have 
different dispersions in PMMA due to the different degrees of intercalation, exfoliation and particle size which ultimately influenced their flammability behaviour.

Among the polyolefin/OMC NCs and polyesterclay NCs, thermoplastic polyurethane (TPU)/OMC NCs are widely studied. It is well-known that polyurethane properties can easily be tailored due to the range of raw materialsavailable for their synthesis. Thus, different macromolecular architectures of PUs can be designed for their specific applications [17]. Transport properties of TPU/OMG NCs used as barrier materials and the effect of OMC processing conditions on NC properties was studied by Herrera-Alonso et al [18]. TPU/MMT NCs were generated by solution mixing and tested as gas barrier membranes. A major difference in the preparation of organically modified MMT (OMMMT) was that they were first sonicated, than solution mixed with the polymer matrix. Samples of TPU/OMMMT prepared using only stirring to disperse the OMMMT, were prepared as reference. In the case of the sonicated OMMMT, better barrier properties were achieved compared with solution stirred OMMMT because of the enhanced dispersion caused by sonication, suggesting permeation was highly sensitivetothe processing method. Astudy of the viscoelastic behavior of TPU/OMC NCs prepared by melt blending followed by compression molding, was reported by Barick and Tripathy [19]. The obtained rheological data revealed a gradual increase of the storage modulus with OMC content in the low frequency region. This increase in storage modulus was attributed to the TPU-OMMT interaction. Similar to rheological studies of the maleic anhydride modified PP/MMT NCs [13], complex viscosity vs. frequency of TPU/OMMT melt was sharply decreased with the addition of MMT clay due tothe shear thinning effect $[19,20]$. In a recent study by Strankowski et al [21], TPU/OMMT NCs with improved mechanical, thermal, dynamic mechanical and rheological properties were reported. The effect of OMMT on the TPU matrix containing a different hard-segment concentration was evaluated through different characterization methods. The improved properties of the TPU/OMMT NCs wasattributedto the exfoliated/ intercalated OMMT structure being uniformly dispersed in the TPU as well as a strong interaction or compatibility of the OMMTA and TPU matrix.

Biopolymer-OMC NCs represent another important group of polymeric materials reinforced with $\mathrm{OMC}$ due to their environmentally friendly nature and sustainability. Botana et al [22] investigated the effects of MMT blended with a biodegradable poly(hydroxybutyrate) (PHB), generating a (PHB)/ MMT nanocomposite. PHB NCs with two types of commercially available MMT clays (i.e. $\mathrm{Na}^{+}$-MMT and OMMMT) were prepared through melt-mixing followed by characterization of morphology, mechanical properties and thermal stability. The dispersion of MMT clays in PHB was observed using TEM. By varying the time of mixing in the Brabender mixer, different degrees of dispersion were observed. The best dispersion of MMT clays was achieved after 30 minutes of mixing. However, thermal degradation of PHB during processing must be considered becausethermal degradation of unmixed PHB occurs at temperatures lower than the melting point of PHB. In this research, chosen processing parameters did not affect thermal degradation of PHB, thus mechanical properties were not influenced over the mixing period. DSC analysis revealed no change in the degree of crystallization and melting point by incorporation of the filler. However, the spherulite size over the crystallization of the molten PHB and PHB NCs (Fig. 4), and non-isothermalcrystallization temperature $\left(T_{\mathrm{c}}\right)$ of PHB were affected by incorporation of MMT clays compared with the neat PHB. PHBs $T_{c}$ was shifted toward higher values in the presence of MMT clays. The improved modulus of the $\mathrm{PHB} / \mathrm{MMT}$ NCs is attributed to the good dispersion of filler in PHB while tensile strength was not changed significantly due to the low exfoliation/intercalation ratio. This ratio was not high enough to increase the tensile strength of the matrix. Burning tests revealed that NC with OMMMTsmaintainedtheir integrity after burning with no liquid dripping observed. It is important to mention that, when dealing with clay- polyhydroxyalkanoates (i.e. PHB, poly(hydroxybutyrate) (PHB) andpoly(hydroxybutyrate-co-hydroxyvalerate) (PHBV)) NCs, the influence of ammonium surfactants on thermal- and thermo-mechanical degradation must be considered. Bordes et al [23] found that all surfactants based on quaternary ammonium cations (Tab. 1) have an effect on the degradation of the polymer matrix especially when the initial molecular weight of the polymer is low.

\section{SUMMARY}

Organically modified clay-polymer NCs have been an intensively studied materials over the past decade. Clays are utilized as fillers within the polymer matrix, due to their natural availability and low price.The most commonly used clay is MMT. A major challenges when dealing with NCs is proper exfoliation/intercalation of clay layers to achieve proper dispersion in the polymer matrix. True 
nanocomposites can be obtained only if single layers are dispersed in the polymer matrix. The most commonly targeted properties for polymer/clay NC include improvement ofmechanical properties, thermal stability and barrier properties.

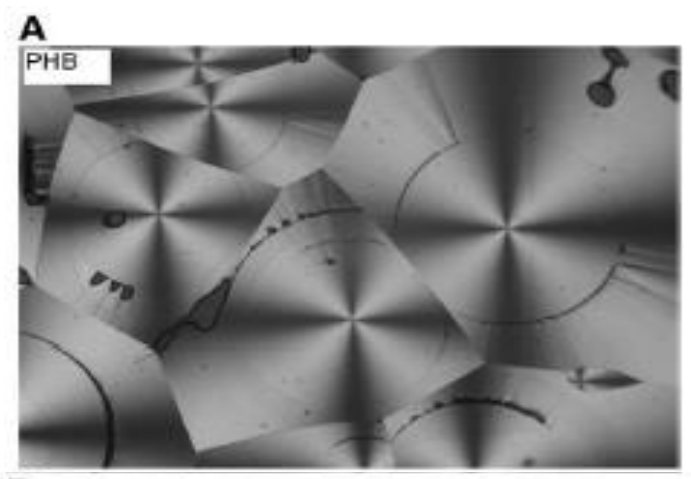

B
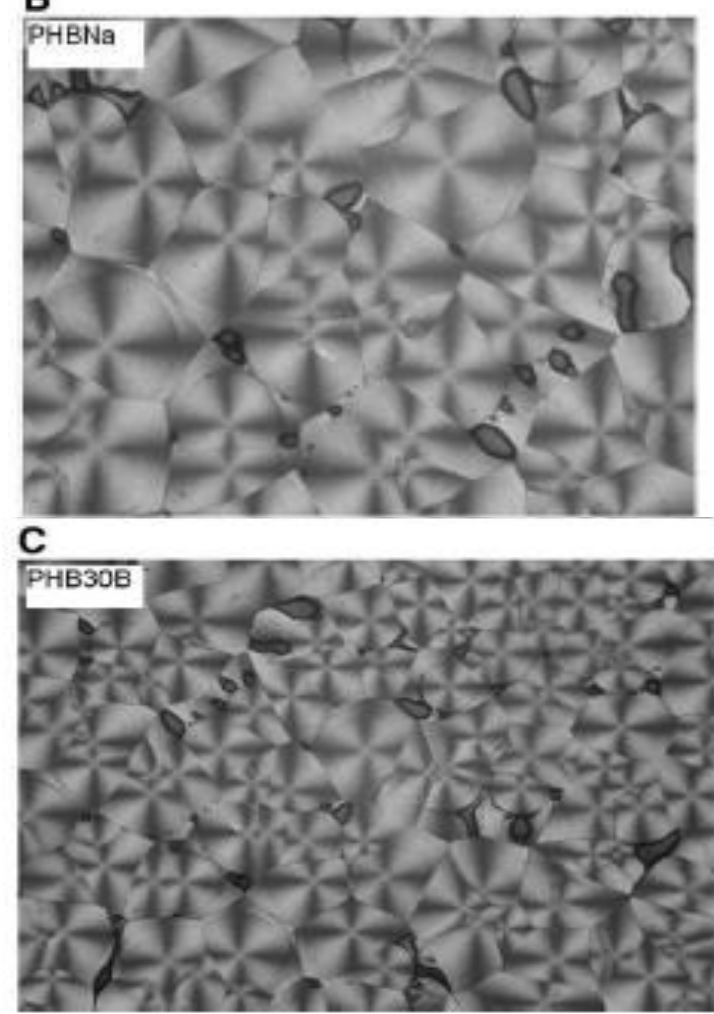

Figure 4-Polarized optical microscopy photographs of PHB NCs [22].

Good barrier properties are essential for the food packaging industry. As reviewed in this report, polyolefin-clay, polyester-clay and TPU-clay NCs were the most studied materials. However, biobased polymers-clay NCs with improved properties have also been investigated.

\section{REFERENCES}

[1] Kotsilkova R., Thermoset nanocomposites for engineering applications, Smithers Rapra, 2007.

[2] Pinnavaia T.J., Beall G.W., Polymer-Clay Nanocomposites, Wiley, 2000.
[3] Hu H., Onyebueke L., Abatan A. (2010): Characterizing and modeling mechanical properties of nanocomposites-review and evaluation, J Miner Mater Charact Eng, 9, pp.275-319.

[4] Hohenberger W., Fillers and Reinforcements/Coupling Agents, In: Plast. Addit. Handb., Hanser, 2001.

[5] Song P., Cao Z., Cai Y., Zhao L., Fang Z., Fu S. (2011): Fabrication of exfoliated graphene-based polypropylene nanocomposites with enhanced mechanical and thermal properties, Polymer, 52, pp.4001-10.

[6] Encyclopedia of Polymer Science and Technology, Wiley, 2002.

[7] Nielsen L.E., Landel R.F., Mechanical Properties of Polymers Composites, 2nd ed., CRC Press, 1994.

[8] LeBaron P.C., Wang Z., Pinnavaia T.J. (1999): Polymer-layered silicate nanocomposites: an overview, Appl Clay Sci, pp. 11-29.

[9] Liu P. (2007): Polymer modified clay minerals: A review, Appl Clay Sci, 38, pp. 64-76.

[10] Rybiński P., Janowska G., Jóźwiak M., Pająk A. (2012): Thermal stability and flammability of butadiene-styrene rubber nanocomposites, J Therm Anal Calorim, 109, pp. 561-71.

[11] Baniasadi H, Ramazani S. A. A., Javan Nikkhah S. (2010): Investigation of in situ prepared polypropylene/clay nanocomposites properties and comparing to melt blending method, Mater Des, 31, pp. 76-84.

[12] Olewnik E., Garman K., Czerwiński W. (2010): Thermal properties of new composites based on nanoclay, polyethylene and polypropylene, J Therm Anal Calorim, 101, pp. 323-9.

[13] Ataeefard M., Moradian S. (2011) Polypropylene/ Organoclay Nanocomposites: Effects of Clay Content on Properties, Polym Plast Technol Eng, 50, pp. 732-9.

[14] Litchfield D.W., Baird D.G. (2006): The rheology of high aspect ratio nano-particle filled liquids, Rheol Rev, pp. 1-60.

[15] Nikolaidis A.K., Achilias D.S., Karayannidis G.P. (2011): Synthesis and Characterizationof PMMA/ Organomodified Montmorillonite Nanocomposites Prepared by in Situ Bulk Polymerization, Ind Eng Chem Res, 50, pp. 571-9.

[16] Wang L., Xie X., Su S., Feng J., Wilkie C.A. (2010): A comparison of the fire retardancy of poly(methyl methacrylate) using montmorillonite, layered double hydroxide and kaolinite, Polym Degrad Stab, 95, pp. 572-8.

[17] Petrović Z.S., Polyurethanes, In: Handb. Polym. Synth., Marcel Dekker, 2005.

[18] Herrera-Alonso J.M., Marand E., Little J.C., Cox S.S. (2009): Transport properties in polyurethane/clay nanocomposites as barrier materials: Effect of processing conditions, J Memb Sci, 337, pp. 20814. 
[19] Barick A.K., Tripathy D.K. (2011): Effect of organically modified layered silicate nanoclay on the dynamic viscoelastic properties of thermoplastic polyurethane nanocomposites, Appl Clay Sci, 52, pp. 312-21.

[20] Barick A.K., Tripathy D.K. (2010): Thermal and dynamic mechanical characterization of thermoplastic polyurethane/organoclay nanocomposites prepared by melt compounding, Mater Sci Eng A, 527, pp. 812-23.

[21] Strankowski M., Stramkowska J., Gazda M., Piszczyk L., Nowaczyk G., Jurga S. (2012):
Thermoplastic polyurethane/(organically modified montmorillonite) nanocomposites produced by in situ polymerization, Express Polym Lett, 6, pp. 610-9.

[22] Botana A., Mollo M., Eisenberg P., Torres Sanchez R.M. (2010): Effect of modified montmorillonite on biodegradable PHB nanocomposites, Appl Clay Sci, 47, pp. 263-70.

[23] Bordes P., Hablot E., Pollet E., Avérous L. (2009): Effect of clay organomodifiers on degradation of polyhydroxyalkanoates, Polym Degrad Stab, 94, pp. 789-96.

\section{IZVOD}

\section{ORGANOGLINA-POLIMERNI NANOKOMPOZITI}

Svojstva polimernih nanokompozita prevazilaze svojstva uobičajenih kompozitnih materijala zbog nanodimenzija i morfologije upotrebljenih punioca. Čestični punioci se uglavnom koriste u cilju poboljšnja mehaničkih $i$ toplotnih svojstava polimera, kao i za modifikovanje električnih svojstava polimerne matrice i smanjenja cene koštanja. Organski modifikovane slojevite gline, kao što je montmorilonit, su između ostalih, najzastupljeniji punioci u upotrebi za poboljšanje svojstava polimernih matrica. Ovim preglednim radom biće prikazani najznačajniji i najviše proučavani glina-polimerni nanokompoziti, kao što su glina-poliolefini, glina-poliestar i glina-termoplastični poliuretan nanokompoziti. Takođe, svojstva biopolimer-glina nanokompozita biće predstavljena i razmatrana u radu.

Ključne reči: organski modifikovane gline, montmorilonit, polimeri, nanokompoziti, svojstva

Pregledni rad

Primljeno za publikovanje: 26.02.2014.

Prihvaćeno za publikovanje: 16. 04. 2014. 